\title{
PERSEPSI MAHASISWA SURABAYA TERHADAP PEMBERITAAN VAKSINASI COVID-19 PADA SOSIAL MEDIA INSTAGRAM (Studi pada Akun Instagram @dr. Tirta)
}

\author{
Rista Dwi Lestari ${ }^{1}$, Dina Safira Putri ${ }^{2}$, Dwi Nuning Anggraeny ${ }^{3}$, Ririn Puspita Tutiasri ${ }^{4}$ \\ ${ }^{1,2,3,4}$ Program Studi Ilmu Komunikasi, UPN “Veteran” Jawa Timur \\ Email: dwinuninganggraeni2@gmail.com
}

\author{
Submitted: 10 Agustus 2021| Accepted: 30 Desember 2021 | Published: 31 Desember 2021 \\ Website: https://e-journal.umc.ac.id/index.php/jike/index \\ DOI: https://doi.org/10.32534/jike.v5i1.2051
}

\begin{abstract}
In order to prevent COVID-19 spread, Indonesian government has declared a prevention strategy of vaccination towards the community at the end of this year. Vaccination programs eventually contribute pros and cons which responding to upcoming executions. Experts and community representatives have to explain the emergence of vaccines throughout their social media accounts. During the pandemic, social media has been working effectively as a better option to spread knowledge and regulations of the viruses. Accessibility of information-contained digital technology, particularly on social media platforms such as Instagram, has a significant impact on public perceptions.

This research looked at how students in Surabaya responded to information about the Covid-19 vaccine on dr.Tirta's Instagram page. using a qualitative approach and data collection techniques by conducting online interviews. Based on result using 8 college student participants in the 20-26 years age group, 6 out of 8 participants agrees on vaccination which posted on dr. Tirta's Instagram fully educates them because the information is accompanied by an appropriated data which motivates the students willing to do vaccinate Covid19. The information of Covid-19 on dr. Tirta's Instagram creates a powerful impact on students' perception in term of Covid-19 vaccination. Thus, it makes them glad to do the vaccination.
\end{abstract}

Keywords: Covid-19 Pandemic, Social Media, Perception

\begin{abstract}
Abstrak
Dalam rangka melakukan percepatan penanganan penyebaran COVID-19 di Indonesia, Pemerintah Republik Indonesia telah mengeluarkan wacana vaksinasi untuk masyarakat Indonesia pada akhir tahun 2020. Kegiatan vaksinasi menimbulkan polemik baru kepada masyarakat. Berbagai stigma positif dan negatif yang pada masyarakat. Para ahli dan tokoh masyarakat menjelaskan pentingnya vaksinasi Covid-19 melalui akun media sosial mereka. Media sosial menjadi medium baik pada pandemi Covid-19 saat ini, sebagai sarana berbagi informasi dan kebijakan mengenai Covid-19. Ketersediaan informasi pada teknologi digital, terutama pada media sosial instagram sangat berpengaruh terhadap pembentukan persepsi masyarakat. Pada penelitian ini membahas mengenai bagaimana persepsi mahasiwa di Surabaya terhadap informasi Vaksinasi Covid-19 pada media sosial instagram dr. Tirta. Dengan menggunakan metode pendekatan kualitatif dan menggunakan teknik pengumpulan data dengan melakukan wawancara secara daring.

Berdasarkan hasil penelitian yang dilakukan dengan menggunakan 8 informan mahasiswa dengan rentan usia 20-26 tahun, 6 dari 8 informan menyatakan bahwa postingan mengenai vaksinasi pada akun media sosial instagram dr. Tirta sangat mengedukasi mereka dikarenakan informasi yang disertai data yang akurat. Hal ini dapat membuat mahasiswa bersedia untuk melakukan vaksinasi Covid-19. Informasi vaksinasi Covid-19 pada akun media sosial instagram dr. Tirta sangat berpengaruh terhadap persepsi mahasiswa mengenai vaksinasi Covid19 serta dapat merubah tindakan mahasiswa dengan bersedianya untuk melakukan Vaksinasi Covid-19.
\end{abstract}

Kata Kunci: Pandemi Covid-19, Media Sosial, Persepsi 


\section{A. PENDAHULUAN}

Seluruh penjuru dunia digemparkan dengan kehadiran sebuah virus yang disebut dengan virus Corona. Virus dengan nama ilmiah SARS-CoV-2 atau memiliki nama awam Covid-19 menyebar dengan sangat ganas di Wuhan. Riset Harvard University mengemukakan konsensus ilmiah asal mula pandemi Covid 19 yaitu patogen SARS-CoV-2 yang mampu untuk melompat dan berpindah dari inang binatang ke manusia yang berada di pasar ikan huanan, China. Gangguan yang dialami sebagian besar individu yang terinfeksi Covid 19 akan mengalami gangguan pernapasan ringan hingga sedang. Individu dengan usia lanjut dan yang memiliki riwayat masalah medis akan cenderung dapat terinfeksi dengan kasus yang lebih serius.

Penyebaran virus corona terjadi secara masif diberbagai negara, termasuk di Indonesia. Pada tanggal 2 maret 2020 pemerintah indoensia secara resmi mengumumkan kasus pertama penyebaran COVID-19 yang berjumlah 2 orang (Kompas, 2020). Kemudian pada tanggal 12 Maret 2020, ditemukan kasus meninggal yang diakibatkan oleh COVID-19. Kasus pertama yang terjadi di indonesia menyebabkan kegaduhan dikalangan masyarakat. Tindakan pencegahan resmi dikerlurakan oleh pemerintah dengan melakukan penerapan protokol kesehatan. Terhitung pada tanggal 28 Desember 2020 kasus positif COVID-19 di Indonesia telah mencapai 719.219 jiwa dengan jumlah kesembuhan mencapai 589.978 jiwa dan kasus meninggal telah mencapai 21.452 jiwa (Prastiwi, 2020). jumlah manusia yang terinfeksi akan terus bertambah dengan seiring waktu sebelum ditemukannya sutau penawar untuk mematikan virus Covid-19.

Dengan semakin bertambahnya kasus positif Covid 19, menyebabkan perubahan secara besar dalam tata kehidupan manusia. Penetapan protokol kesehatan, mendorong berbagai sektor bidang kehidupan. Perubahan tata aturan ini mengakibatkan terjadinya kemrosotan ekonomi mulai dari sektor pemerintah, pariwisata, transportasi, industri, dan berbagai bidang lainnya.

Pada tanggal 28 Desember Menteri Luar Negeri, Retno Marsudi resmi melakukan penutupan sementara seluruh kedatangan Warga Negara Asing (WNA) ke Indonesia. Keputusan ini dikeluarkan sebagai antisipasi kemunculan varian baru dari Covid 19. Penutupan dilakukan pada tanggal 1-14 Januari 2021 (Hidup et al., 2020a). Dengan adanya keputusan tersebut mengakibatkan sektor wisata mengalami penurunan ekonomi. Sektor pariwisata mempunyai sumbangsih yang besar terhadap negara yang mencapai 15 miliyar dillar AS. Dengan adanya pandemi devisa sektor pariwisata menurun hingga 90 persen.

Berbagai lini sektor bidang negara terdampak dengan adanya wabah virus corona tak terkecuali dengan proses pemerintahan di indonesia. Pada akhir tahun 2020 indonesia dihadapkan dengan proses pemilihan kepala daerah di beberapa daerah di indoensia. Kegiatan tersebut menimbulkan polemik pro dan kontra untuk direalisasikannya proses pemilihan calon wakil rakyat. KPU sebagai pengawas dan pembuat keputusan terhadap proses pemilihan telah mengeluarkan 2 peraturan KPU erbaru yaitu PKPU Nomor 13 Tahun 2020 tentang Pelaksanaan Pilkada Serentak 2020 di era pandemi Covid 19 yang berasal dari revisi PKPU Nomor 6/2020 dan PKPU Nomor 11/2020 tentang Perubahan atas PKPU No 4/2017 tentang Kampanye Pemilihan Kepala daerah sampai dengan sosialisasi dan simulasi pemungutan suara dengan penerapan protokol kesehatan yang ketat (Astuti, 2020). Dengan adanya peraturan tersebut segala pihak yang terlibat dapat menerapkan sebagai suau pedoman yang harus dilakukan agar proses pemilihan kepala daerah dapat terealisasikan dengan aman.

Covid 19 telah ditetapkan oleh WHO sebagai darurat kesehatan global. Segala upaya dilakukan pemerintah untuk mencegah penyebaran virus corona secara lebih masif yaitu dengan melakukan penerapan protokol kesehatan. Dengan adanya situasi tersebut, salah satu cara yang 
efektif dan memungkinkan untuk mencegahh semakin luasnya penyebaran virus Covid 19 yaitu melalui vaksinasi. Pengembangan pembuatan vaksin Covid 19 telah dilakukan di berbagai negara didunia.

Pelaksanaan vaksin Covid 19 telah diatur dan ditetapkan urutan bagi warga Indonesia yang akan diberikan suntikan vaksin Covid 19. Aturan ini terdapat dalam Pemernkes No.84 tahun 2020 tentang pelaksanaan vaksinasi dalam rangkah penanganan virus Covid 19 yang telah ditandatangani oleh Menteri Kesehatan Terawan Putranto dan Berlaku sejak 14 desember 2020.

Untuk orang pertama yang akan menerima vaksin Covid 19 yang telah mendapatkan izin penggunaan darurat dari Badan Pengawasan Obat - obatan Dan makanan (BPOM) ialah presiden Joko widodo. Presiden Jokowi menjelaskan bahwa vaksinasi Covid 19 akan dilakukan pada januari 2021 dan diharapkan semua masyarakat Indonesia mendapatkan vaksin tersebut. Akan tetapi memerlukan beberapa waktu untuk disuntikkan kepada masyarakat, karena data terakhir yang diperoleh dari masyarakat yang divaksin sebanyak 182 juta masyarakat. Pemerintah akan melakukan vaksinasi Covid-19 lewat dua tahap Pertama, vaksin program di mana vaksin corona akan digratiskan untuk $30 \%$ warga. Kedua, vaksin akan dilakukan secara mandiri yang mana akan dijual kepada $70 \%$ dari sisa target penerima vaksin gratis.

Dalam pemberian vaksinisasi Covid 19 ini juga terjadi pro dan kontra baik dilakangan masyarakat dan pemerintah. Untuk pemerintah sendiri masih terjadinya pro dan kontra dimana dari mohammad faisal selaku Ekonomi CORE Indonesia melihat terjadinya kepincangan antara kedua tahap tersebut. Karena pemerintah masih memiliki kelonggaran anggaran untuk memperluas jumlah penerima vaksin graris. Sisa anggaran Pemulihan Ekonomi - Ekonomi (PEN) 2020 yang kemungkinan masih ada bisa menjadi salah satu alternative.

Untuk dikalangan masyarakat sendiri masih banyak yang takut dengan vaksin tersebut, belum lagi adanya pemberitaan tentang berbagai macam efek samping dari vaksin Covid 19 ini.Mereka menganggap bahwa mereka hanya dijadikan kelinci percobaan untuk penemuan vaksin tersebut. Dan masih ada kelompok yang tidak boleh disuktik vaksin Covid 19 seperti: ibu hamil dan yang belum direkomendasikan untuk suntik vaksin, orang dengan riwayat alergi parah, penderita kanker yang menjalani kemoterapi, para penerima transplatasi, dan pengidap HIV/AIDS.

Dari beragam pemberitaan yang disampaikan mengenai vaksin Covid 19 menyebabkan banyak munculnya pro dan kontra serta persepsi dikalangan masayarakat. Persepsi sendiri merupakan inti dari komunikasi. Setiap kegiatan komunikasi baik itu intra personal maupun melibatkan orang lain akan berhubungan dengan persepsi. Dikarenakan persepsi merupakan hasil kontak langsung indra kita dengan berbagai rangsangan baik yang berasal dari manusia atau lingkungan fisik. Dalam pemberitaan vaksin civid 19 ini menimbulkan banyak persepsi terutama pada keluarga, karena keluarga juga memiliki resiko penularan Covid 19 apabila salah satu anggota keluarga mereka terkena Covid dan akan menularkan ke anggota lainnya sehingga satu rumah dapat tertular Covid 19.

Penyebaran berbagai informasi pemberitaan mengenai vaksinasi Covid-19 dapat melalui berbagai jenis media digital. Salah satunya yaitu media sosial instagram, instagram merupakan media sosial yang banyak digandrungi oleh kalangan generasi millenial dan generasi Z. Berbagai fitur dan juga kemudahan di sediakan oleh instagram. Salah satunya yaitu kemudahan dalam mencari informasi Covid-19 baik yang diposting oleh perseorang maupun organisasi. Salah satu postingan perseorangan ( Influenzer) mengenai vaksinansi Covid-19 yang sedang populer yaitu dr. Tirta. Dokter sekaligus mantan satuan tugas Covid-19 memiliki nama lengkap Tirta Mandira Hudhi. Dokter Tirta memiliki nama username media sosial instagram yaitu $d r$.Tirta. Terkenal dengan gaya penyampaian edukasi mengenai vaksinasi Covid-19 yang sangat unik. Keunikan dr.Tirta terlihat dari kostum berbusana khas mahasiswa. 
Serta cara komunikasi yang unik, dokter Tirta sangat lantang dan terus terang terhadap kenyataan yang ada dilapangan mengenai perkembangan Covid-19 di indonesia.

Berbagai ciri khas yang dimiliki dr. Tirta. Membuat banyak masyarakat men aruh kepercayaan terhadap informasi yang disampaikan oleh dr. Tirta. Cara edukasi yang dilakukan juga melalui postingan yang disebarkan oleh akun pribadi dokter Tirta. Postingan instagram dokter Tirta memberikan edukasi yang benar mengenai hoax Covid 19 yang tersebar di masyarakat. Penyampaian edukasi melalui instagram disertai dengan bukti kongkrit dan penjelasan yang mudah di pahami oleh masyarakat. Akun instagram dr.Tirta melalui postingannya memberikan klarifikasi dan pembenaran terhadap informasi tidak benar mengenai informasi Covid 19 dengan menyertakan data yang valid.

Didalam situasi pandemi Covid-19. Sebagai masyarakat bukan hanya melalukan pencegahan dan perlindungan diri dari Covid-19 tetapi juga harus melindungi diri dari adanya berbagai informasi palsu atau hoax yang bertebaran di masyarakat. Pencegahan terhadap informasi palsu dapat kita hindari dengan tidak mudah percaya terhadap informasi yang ada dan melakukan pengecekan informasi pada pihak dan institusi yang terpecaya dan dapat dipertanggung jawabkan.

Tentu semua pasti waspada dengan adanya Covid - 19 ini banyak cara - cara penjegahan untuk melindungi diri. Perlindungan diri untuk diri sendiri itu yang utama, selanjutnya dengan adanya pemberian vaksin untuk pencegahan Covid - 19 ini juga menjadi salah satu upaca untuk pencegahan Covid - 19. Apalagi dengan adanya pemberitaan simpang siur di media sosial yang dapat menarik perhatian dari banyak orang khususnya mahasiswa. Mahasiswa sendiri terkenal dengan sangat kritis dalam menanggapi pemberitiaan khususnya pada media sosial.

Media sosial memiliki peran penting dalam kehidupan sehari - hari masyarakat sebagai media untuk berbagi informasi dan komunikasi mengenai hal - hal yang ada disekitar kita, mulai dari kegiatan sehari - hari, politik, ekonomi, budaya, sampai pada pemberitaan pemberitaan yang saat ini sedang trend di kalangan masyarakat. Namun masih banyak pengguna media social yang kurang memahami manfaat dan fungsi dari media social dengan baik, sehingga banyak orang yang menyalahgunakan dalam penggunaan media social.

Kemajuan teknologi sangat diperlukan oleh manusia. Keinginan seseorang untuk menggunakan produk teknologi teramat dipengaruhi oleh persepsi. Persepsi ialah suatu proses yang dimulai dari penggunaan panca indera dalam memperoleh stimulus, kemudian diorganisasikan dan diinterpretaikan sehingga memiliki pemahaman tentang apa yang di indera. Persepsi juga dapat dikatakan sebagai proses penyampaian pesan atau informasi yang masuk ke dalam otak manusia (Saifuddin, 2018).

Untuk mahasiswa sendiri sangat mengkritisi pemberitaan pada media sosial salah satunya media sosisal instagram, dimana media social dapat menimbulkan banyak persepsi baik dan buruk terutama dalam kalangan mahasiswa. Dalam pemberitaan vaksin Covid - 19 ini juga banyak para tokoh yang menanggapi dan memberikan saran untuk vaksin tersebut melalui akun media sosial Instagram mereka, salah satu tokohnya yaitu dr. Tirta. Akun instagram dr. Tirta sendiri dalam postingannya di instagram banyak sekali memberikan informasi baik itu tentang Covid-19 maupun vaksin Covid-19 dalam postingan tersebut dapat menimbulkan banyak persepsi dan tanggapan - tanggapan baik itu positif maupun negative.

Persepsi merupakan proses yang menyangkut masuknya pesan atau informasi ke dalam setiap otak individu. Persepsi merupakan sesuatu yang bersifat subjektif, tergantung dari pengalaman pribadi dan latar belakang yang dimiliki masing- masing individu. Inilah mengapa informasi yang diterima setiap individu dapat mempengaruhi persepsi yang dimiliki. Jadi dalam postingan instagram dr. Tirta nantinya akan menimbulkan banyak persepsi baik positif 
maupun negative dari para pengikutnya, tergantung bagaimana cara mereka mempersepsikan informasi mengenai vaksin Covid - 19 tersebut.

Dalam postingan dr. Tirta sendiri dalam akun instagramnya yang sangat menarik sehingga dalam akun instagram beliau banyak sekali pengikut terutama anak mudah dan banyak juga dari kalangan mahasiwa. Dari postingan dr. Tirta yang menarik itu dapat sekali memiliki tanggapan dari berbagi kalangan dan juga dari kalangan mahasiswa yang dapat membuat mahasiwa tersebut menggangapi secara kritis dari postingan tersebut dan memberikan informasi tentang vaksin Covid - 19 terhadap banyak orang terutama juga pada kalangan mahasiswa. Dikarenakan mahasiswa yang kritis dalam menerima pemberitaan vaksin Covid -19 jika para mahasiwa tidak mencari informasi yang benar makan akan dapat menimbulkan banyak persepsi yang dapat membuat terjadinya pro dan kontra sendiri dalam kalangan mahasiwa didalam pemberitaan vaksin Covid -19 .

\section{B. METODE PENELITIAN}

Metode ini menggunakan kualitatif deskriptif dimana peneliti ditempatkan sebagai instument kunci. Teknik pengumpulan data digunakan dengan wawancara secara daring. Dan uraian data secara deskriptif dari hasil wawancara yang telah dilakukan. Menurut Iii \& Penelitian ( 2013), penelitian kualitatif mengolah dan menghasilkan data yang bersifat deskriptif seperti transkip wawancara dan observasi.

Dalam penelitian kualitatif, kualitas riset sangat tergantung pada kualitas dan kelengkapan data yang dihasilkan. Pertanyaan yang selalu diperhatikan dalam pengumpulan data adalah apa, siapa, dimana, kapan dan bagaimana. Penelitian kualitatif bertumpu pada triangulasi data yang dihasilkan dari tiga metode : interview, participan to observation, dan telaah catatan organisasi (document records). Dalam penelitian kualitatif pengumpulan data lazimnya menggunakan metode observasi, dokumentasi dan wawancara. Juga tidak diabaikan kemungkinan menggunakan sumber - sumber non-manusia (non-human source of information) seperti dokumen dan rekaman (record) yang tersedia. Pelaksanaan pengumpulan data ini juga melibatkan berbagai aktivitas pendukung lainnya seperti menciptakan rapport, pemilihan informan, pencatatan data/informasi hasil pengumpulan data. Karena itu dalam bagian ini akan dibahas secara berturut-turut; penciptaan rapport, pemilihan informan, pengumpulan data dengan metode observasi, dokumentasi, wawancara, pengumpulan data dari sumber non-manusia dan pencatatan data/ informasi hasil pengumpulan data.

\section{Informan Penelitian}

Menurut Ardian (2013) pengertian populasi adalah "wilayah generalisasi yang terdiri dari atas objek atau subjek yang mempunyai kuantitas dan karakteristik tertentu yang ditetapkan oleh peneliti untuk dipelajari dan kemudian ditarik kesimpulannya". Setiap pengerjaan penelitian tidak terlepas dari objek dan subjek penelitian. Melalui objek penelitian tersebut akan diperoleh variabel - variabel yang menjadi permasalahan sekaligus merupakan sumber data yang akan di teliti. Objek yang ditetapkan untuk diteliti adalah populasi. Populasi dalam penelitian ini adalah masyarakat kota Surabaya dengan kriteria sebagai berikut : a. mahasiswa kota Surabaya, b. wanita atau pria, c. mahasiswa yang mengikuti akun instagram dokter Tirta, d. mahasiswa yang mengetahui tentang postingan dokter Tirta mengenai vaksin Covid - 19 e. memiliki rentan usia 20 - 26 tahun.

Setelah melakukan klasifikasi informan yang sesuai dengan kebutuhan, maka diperoleh 8 informan, sebagai berikut:

Tabel 1. Data Informan 


\begin{tabular}{|c|l|l|l|}
\hline No & \multicolumn{1}{|c|}{ Nama Inisial } & \multicolumn{1}{c|}{ Usia } & \multicolumn{1}{|c|}{ Jenis Kelamin } \\
\hline 1. & VH & 20 tahun & Wanita \\
\hline 2. & DST & 20 tahun & Wanita \\
\hline 3. & AW & 20 tahun & Pria \\
\hline 4. & JS & 24 tahun & Pria \\
\hline 5. & AP & 23 tahun & Pria \\
\hline 6. & SD & 20 tahun & Wanita \\
\hline 7. & A & 21 tahun & Pria \\
\hline 8. & CES & 20 tahun & Wanita \\
\hline
\end{tabular}

Sumber : penelitian, 2021

\section{HASIL PENELITIAN DAN PEMBAHASAN}

Penelitian ini berjudul persepsi mahasiswa Surabaya terhadap pemberitaan vaksinasi Covid-19 pada media sosial Instagram (Akun dr. Tirta). Dalam perspektif ilmu komunikasi, persepsi merupakan inti komunkasi yaitu proses dimana kita melakukan penafsiran data sensoris yakni data yang diterima melalui panca indera kita.

Pada penelitian ini terdapat beberapa kriteria informan berdasarkan kriteria yang telah ditetapkan yaitu mahasiwa berusia 20-26 tahun. Kurniawati \& Baroroh (2016) mahasiswa merupakan seseorang yang terdaftar secara resmi pada salah satu perguruan tinggi negeri maupun swasta untuk mengikuti pendidikan. Peneliti memperoleh data dari 8 informan. Berdasarkan dari 8 informan yang peneliti wawancara, memberikan hasil dari persepsi mahasiswa terhadap postingan pada media sosial instagram dr. Tirta mengenai vaksinasi Covid 19.

\section{Instagram Sebagai Sumber Informasi Pada Pandemi Covid-19}

Media sosial merupakan media online yang memudahkan dalam melakukan interaksi sosial. Sosial media merupakan teknologi dengan berbasis web yang dapat mengubah komunikasi menjadi dialog yang interaktif. Media sosial yang sering digunakan oleh para generrasi muda yaitu instagram. Media sosial instagram adalah platform digital yang sering digunakan oleh sebagian besar kalangan millenials di dunia terutama di Indonesia. Media sosial instagram menyediakan fasilitas untuk berbagi foto maupun video dengan menerapkan beberapa filter digital yang dapat memancing pengguna yang penasaran dengan kecanggihan dari instagram.

Ma'ruf (2017) instagram saat ini bukan hanya digunakan untuk kepentingan pribadi tetapi diperlukan beberapa orang yang memanfaatkan instagram sebagai wadah untuk bertukar informasi dari satu orang ke orang lain ataupun kelompok yang lebih luas. Fungsi media sosial tidak lepas dari cyberspace, "cyberspace menjelaskan bahwa terdapat tempat dimana ia tidak nyata tetapi keberadaannya dapat dirasakan bahkan menjadi kenyataan dalam benak. Dengan berbagai fitur instagram yang canggih, instagram kemudian dipandang sebagai media sosial dengan efek yang luas dan menjanjikan.

Pemanfaatan media sosial instagram sebagai wadah untuk bertukar informasi dari satu orang ke orang lain sejalan dengan pernyataan informan 1, 2, 3, dan 10.

Informan 1

"Biasanya aku menggunakan instagram bukan hanya untuk hiburan saja tetapi untuk berbagi informasi antara aku dan temen yang memiliki kesamaan topik" 


\section{Informan 2}

"instagram biasanya saya pakai untuk berbagi informasi dengan sesama teman belajar untuk saling berbagi informasi mengenai pendidikan"

\section{Informan 3}

"lebih sering menggunakan instagram untuk hiburan tetapi juga pernah mencari dan berbagi informasi melalui instagram dengan kelompok lain"

\section{Informan 10}

"iya sering berbagi informasi dari instagram, karena di instagram banyak informasi yang bermanfaat buat saya pribadi”.

Instagram menjadi medium yang sangat bagus pada era visual saat ini, sebagai sarana berbagi informasi kebijakan, kekayaan alam, kesehatan, budaya dan berbagai sektor lainnya seperti berbagai institusi pemerintahan, pendidikan. Tersedianya informasi di era digital ini terutama pada media sosial sangat berpengaruh terhadap pembentukan persepsi publik terhadap informasi kesehatan dan Covid-19. Informasi mengenai Covid-19 melalui media sosial menjadi begitu gencar bahkan dianggap sebagai informasi yang penting.

Rachman \& Pramana (2020) menurut data statistik Hootsuite We Are Sosial, pada bulan Januari 2019 dari 268,2 juta penduduk Indoensia, 150 juta atau 56\%-nya adalah pengguna aktif dari media sosial. Prosentase orang dewasa yang menggunakan media sebagai penyalur informasu, $95 \%$ dari total jumlah penduduk indonesia menggunakan tekevisi dan $91 \%$ menggunakan mobile phone dan $60 \%$ menggunakan smartphone.

Informasi mengenai Covid-19 terlihat sangat banyak berputar di berbagai sosial media seperti instagram bahkan berbagai kampanye dengan menggunakan hastag mengenai Covid19 dan juga tenaga kesehatan sudah menjadi trending. Kampanye ini tidak hanya terjadi di Indonesia, melainkan seluruh dunia. Bahkan bagaimana perjuangan para tim medis yang membantu melawan Covid-19 banyak terupload di media sosial.

Utami (n.d.) sebagian besar dari pengguna internet di Indoneisa merupakan mahasiswa yang merupakan pengguna aktif media sosial. Mahasiswa tidak hanya mengakses 1 platform saja tetapi ada beberapa. Pada urutan teratas, whatsapp menjadi media yang banyak digunakan dengan 95,96\% responden, kemudian instagram dengan 90,91\%. Dengan banyaknya pengguna instagram di Indonesia, banyak pemilik akun instagram yang kini menyediakan berbagai informasi berupa pengetahuan umum, terutama dalam situasi pandemi Covid-19 saat ini diperlukan edukasi yang sangat banyak mengenai apa itu virus corona. Berbagai publik figure yang memahami mengenai dunia kesehatan. Mereka membagikan pengetahuan mereka terhadap Covid-19 kepada masyarakat luas melalui akun media sosial instagram pribadinya. Penyebar informasi mellaui media sosial sangat efektif dikarenakan pada situasi pandemi saat ini masyarakat banyak melakukan komunikasi dan kegiatan sehari-harinya melalui jejaring internet.

\section{Proses Pemahaman Mahasiswa Terhadap Informasi Vaksinasi Covid-19}

Persepsi merupakan serangkaian proses aktif. Persepsi terbentuk dari tigas tahapan pokok:1. Stimulasi atau seleksi, stimulasi merupakan datangnya sebuah sensasi. Sensasi yang menstimulus menimbulkan perhatian pada diri peserta komunikasi. Proses seleksi ini diterima oleh panca indera yang berasal dari stimulus luar. 2. pengelompokan (Organization), setelah melakukan seleksi informasi yang diperoleh, peserta komunikasi lalu akan mengorganisasikan informasi tersbut. Pengelompokan informasi tersebut tergantung dari pengertian yang dimiliki oleh peserta komunikasi. 3. interpretasi-evaluasi, proses selanjutnya yaitu melakukan 
interpretasi dan evaluasi. Kedua proses ini tidak dapat dipisahkan dan tahap ini bersifat sangat subjektif dan dipengaruhi berbagai faktor yang bersifat personal. Faktor personal yang mempengaruhi penilaian seseorang dapat dibagi dalam lima hal : pengalaman terdahulu, asumsi perilaku, ekspektasi, pengetahuan yang dimiliki seseorang, dan perasaan orang tersebut (mood). Pada tahap ini akan terjadi pembentukan kesimpulan.

Pada tahapan yang pertama yaitu proses stumulasi atau seleksi, informan melakukan kegiatan yang akan merangsang stimulus yang berasal dari luar melalui berbagai panca indera yang dimiliki oleh informan. Pada penelitian ini seluruh informan yang berjumlah 8 orang telah melihat dan mencari informasi yang berasal dari akun media sosial instagram dr. Tirta mengenai vaksinasi Covid-19 seperti pernyataan informan 10.

"postingan tgl 27 januari 2021, beliau memposting dari kompas tv yang memberitakan Presiden Jokowi vaksin tahap 2. Presiden sudah vaksin, lalu dalam postingan tersebut menyebutkan bahwa dr Tirta akan divaksin juga".

Selanjutnya pada tahapan kedua yaitu proses pengelompokan. Informan yang telah melakukan stimulasi dengan melihat informasi yang berasal dari akun media sosial instagram dr. Tirta akan melakukan pengelompokan informasi yang sesuai dengan kebutuhan informan. Pengelompokan ini akan bergantung pada kebutuhan informasi setiap individu dan pemahaman informasi setiap informan.

Kegiatan vaksinasi menimbulkan polemik baru kepada masyarakat. Berbagai stigma positif dan negatif yang ada pada masyarakat. Kemunculan berbagai stigma ini berasal dari banyaknya informasi yang tersebar di berbagai media sosial. Informasi yang tidak tepat mengenai vaksinasi memunculkan berbagai pemahaman yang berbeda terhadap vaksinasi. Pengelompokan informasi terjadi pada masing-masing individu yang dipengaruhi oleh pola pikir individu dan pengertian individu terhadap suatu informasi. Berdasarkan hasil wawancara yang dilakukan dari 8 informan yang mengikuti dan mencari informasi vaksinasi pada akun media sosial instragram dr. Tirta terdapat 2 informan yang ragu terhadap informasi mengenai vaksinasi pada postingan akun media sosial instagram dr. Tirta, keraguan ini berasal dari pemahaman informan yang tidak mengetahui sama sekali mengenai dunia kesehatan sehingga kurang percaya terhadap informasi mengenai vaksinasi. Dari 8 informan yang telah mengikuti akun Instagram dr. Tirta, hampir dari ke 8 informan tersebut yang yakin untuk melakukan vaksin Covid - 19. Namun terdapat 2 informan yang masih meragukan postingan dr. Tirta di Instagram mengenai vaksin. Alasan dari tidak setujunya yaitu :

Informan 3

"terdapat sedikit keraguan, yaitu mengenai harga vaksin yang akan dibagi untuk masyarakat apakah akan semua masyarakat mendapatkan vaksin gratis ataukah harus ada biaya untuk melakukan vaksin ini."

\section{Informan 7}

"Ragu, saya sendiri bukan orang berlatar belakang dokter/ilmu biologi, jika hanya saran saran yang informasinya belum tentu valid saya kira masyarakat banyak yang tidak mau jika menyadari itu."

Namun, 6 dari 8 informan menyatakan bahwa tidak ada keraguan yang timbul setelah melihat informasi mengenai vaksinasi pada akun media sosial instagram dr. Tirta.

Informan 1 
"belum ada postingan yang menjadikan saya ragu, dokter Tirta salah satu dokter muda yang mampu mengedukasi masyarakat terutama anak muda, dengan gaya komunikasi yang mudah dipahami dan jelas serta kritis",

\section{Informan 2}

"tidak ada postingan yang membuat saya ragu, Karena fakta yang diberikan relate dengan keadaan yang sedang terjadi. Dan bahasa yang digunakan sesuai denganpemahaman masyarakat pada umumnya”.

\section{Informan 4}

"tidak ada postingan yang saya ragukan"

\section{Informan 5}

"belum ada postingan yang menjadikan saya ragu, karena menurut saya dr. Tirta merupakah salah satu seorang yang mengerti bagaimana kondsi langsung masyarakat saat ini".

\section{Informan 6}

"belum ada postingan yang membuat saya ragu. Karena melalui postingannya sangat mengedukasi masyarakat untuk memahami seputar Covid 19 dan juga vaksinasi”.

\section{Informan 8 \\ "belum ada postingan yang menjadikan saya ragu"}

Kepercayaan yang timbul pada mahasiswa dikarenakan pengelompokan pemahaman yang sama mengenai vaksinasi, yang sangat berguna dalam menekan angka korban penyebaran Covid-19. Perbedaan pemahaman dan pengertian mengenai informasi vaksinasi sangat bergantung pada pola pikir setiap individu dalam memaknai suatu informasi.

Selanjutnya pada tahap yang terakhir yaitu proses interpretasi dan evaluasi ditujukkan dengan berbagai kegiatan dan tingkah laku setelah adanya stimulus dan seleksi sebagai suatu reaksi terhadap pesan yang diterima. Tingkah laku yang muncul sangat tergantung pada faktor personal setiap individu. Faktor personal yang mempengaruhi penilaian seseorang dapat dibagai dalam lima hal : pengalaman terdahulu, asumsi perilaku, ekspetasi, pengetahuan yang dimiliki seseorang dan perasaan orang tersebut (mood).

Bentuk tingkah laku yang timbul pada tahapan ini ditunjukkan dengan ketertarikan informan dalam memahami informasi mengenai vaksinasi Covid-19 serta ketersediaan 6 dari 8 informan untuk melakukan vaksinasi Covid-19, setelah melihat informasi vaksinasi pada akun media sosial instagram dr. Tirta. Dari total 8 informan, 6 diantaranya sangat tertarik terhadap informasi vaksinasi Covid-19 pada akun media sosial instagram dr. Tirtra dan menjadikan instagram dr. Tirta sebagai informasi utama untuk mendapatkan informasi mengenai vaksinasi Covid-19, karena informasi pada instagram dr. Tirta mampu mengedukasi informan. Ketertarikan ini dikarenakan informasi yang ada merupakan informasi yang terpecaya menurut informan dan menyertakan data-data yang mendukung informasi mengenai vaksinasi selain itu gaya komunikasi yang dimiliki dr. Tirta dalam menyampaikan informasi mengenai vaksinasi sangat luwes dan sesuai dengan gaya dari mahasiswa. Sedangkan 2 informan lainnya tidak terlalu tertarik pada informasi vaksinasi Covid-19 dikarenakan pemikiran informan yang menyatakan bahwa tidak mengetahui dunia kesehatan seperti apa 
termasuk vaksinasi, sehingga terdapat keraguan terhadap ke-valid-an informasi vaksinasi yang akan digunakan di indonesia

Hasil penelitian ini dibuktikan dengan penelitian lain (Rachman \& Pramana, 2020) terkait banyaknya persepsi tentang adanya vaksin Covid - 19 di Indonesia. Banyaknya pemikiran orang mengenai vaksin Covid-19, ada yang positif dan negative. Penelitia n lain (Nastiti, Widya, et al., 2020) terkait upaya pemerintah dalam mengurangi persebaran virus Covid - 19 melalui vaksin yang diberikan oleh pemerintah kepada masyarakat Indonesia. 6 dari 8 informan setuju diberikan vaksin Covid - 19 agar dapat menghindarkan dari virus ini. Walaupun di awal banyak dari mahasiswa yang belum paham mengenai manfaat dari vaksin Covid - 19, namun setelah melihat informasi terkait vaksin pada media sosial Instagram pada akun instagram dr.Tirta banyak dari mahasiswa yang mendapatkan penjelasan lebih detail mengenai vaksin dalam akun instagram tersebut. Dari beberapa responden diatas banyak yang memperoleh informasi secara detail mengenai vaksin karena disertai dengan data pendukung yang relevan dan akurat.Informan banyak yang menyetujui apabila mendapatkan vaksin Covid - 19 dari pemerintah. Dalam postingan dr.Tirta sendiri banyak persepsi yang muncul terkait vaksin Covid - 19 ini. Diharapkan untuk orang - orang yang mengetahui postingan vaksin dalam intagram dokter Tirta banyak membawa dampak positif dan menyakinkan masyarakat untuk melakukan vaksinasi Covid-19.

\section{KESIMPULAN}

Kegiatan vaksinasi Covid-19 yang akan dilakukan pemerintah sebagai upaya untuk memutus rantai peneyebaran Covid-19, memiliki respon yang beragam dari kalangan mahasiwa. Edukasi dan penjelasan mengenai betapa pentingnya vaksinasi dikala pandemi Covid-19 saat ini dilakukan oleh berbagai kalangan dari pemerintah sampai dengan influenzer. Tak terkecuali dr. Tirta, sebagai seorang dokter yang mengikuti perkembangan jaman dr.Tirta selalu membagikan informasi mengenai Covid-19 dan vaksinasi pada akun media sosial instagram pribadinya. Postingan mengenai vaksinasi Covid 19 dipaparkan dengan bahasa yang mudah dipahami serta memberikan data pendukung yang valid. Ketertarikan mahasiswa untuk mengikuti akun media sosial instagram dr. Tirta dikarenakan gaya komunikasi yang sesuai dengan anak muda dan informasi yang disampaikan merupakan informasi yang terbaru karena merujuk pada data-data yang terbaru. Dengan melihat informasi melalui postingan instagram dr. Tirta mengenai vaksinasi Covid-19, berdasarkan wawanacara yang dilakukan pada 8 informan, 6 informan menyatakan bersedia untuk melakukan vaksinasi Covid 19. Hal tersebut membuktikan bahwa postingan pada instagram dr. Tirta mengenai vaksinasi Covid-19 mampu mempengaruhi pola pikir dan persepsi mahasiswa sehingga bersedia untuk melakukan vaksinasi Covid-19.

\section{Refrensi}


American Journal of Sociology. (2019). Persepsi Kebutuhan Pendidikan dalam Kesehatan. Journal of Chemical Information and Modeling, 10(1), 126-131. https://doi.org/10.33859/dksm.v10i1.436 Abstrak

Amin, M. Al, \& Juniati, D. (2017). Klasifikasi Kelompok Umur Manusia Berdasarkan Analisis Dimensi Fraktal Box Counting Dari Citra Wajah Dengan Deteksi Tepi Canny. Jurnal Ilmiah MAtematika, 2(6), 33-42.

Ardian, M. (2013). Sikap Masyarakat Surabaya Terhadap Program Acara "Pesbukers"di ANTV. Jurnal E-Komunikasi, 1(1), 1-11.

Astuti, I. (2020). Menjaga Kredibilitas Pilkada di Tengah Pandemi. Mediaindonesia.Com, 1. https://mediaindonesia.com/read/detail/354149-menjaga-kredibilitas-pilkada-di-tengahpandemi

CITRANINGRUM, P. P. (2016). Komunikasi dan Persepsi Mengenai Kepemimpinan Perempuan dalam Masyarakat Jawa. Jurnal Communication. http://www.jurnalkommas.com/docs/JURNAL Prita Permatasari C (D0211080) (1).pdf

Deriyanto, D., \& Qorib, F. (2018). Persepsi Mahasiswa Universitas Tribhuwana Tunggadewi Malang Terhadap Penggunaan Aplikasi Tik Tok. JISIP: Jurnal Ilmu Sosial Dan Politik, 7(2), 77-83. www.publikasi.unitri.ac.id

Dwi, B., Ispriadi, S., Putri, D. A., \& Dewani, P. K. (2020). EKSISTENSI MEDIA CETAK PADA MASA PANDEMI COVID -19. 9(2), 127-134. www.publikasi.unitri.ac.id

El-Dairi, M., \& House, R. J. (2019). Optic nerve hypoplasia. In Handbook of Pediatric Retinal OCT and the Eye-Brain Connection (pp. 285-287). https://doi.org/10.1016/B978-0-323-60984-5.00062-7

Hasibuan, H. I. (2018). Pemberitaan Media Cetak dalam Mempengaruhi Partai Politik untuk Menentukan Calon pada Pemilukada Tahun 2015. Persepsi: Communication Journal, 1(1), 81-96. https://doi.org/10.30596/persepsi.v1i1.2509

Hidup, G., Peristiwa, B., Praperadilan, P., Mesum, C., Coron, K. V., Usai, C. T., \& Usut, S. P. (2020a). Indonesia Tutup Pintu untuk Semua WNA Per 1 Januari 2021. CNN Indonesia.

Hidup, G., Peristiwa, B., Praperadilan, P., Mesum, C., Coron, K. V., Usai, C. T., \& Usut, S. P. (2020b). Indonesia Tutup Pintu untuk Semua WNA Per 1 Januari 2021. CNN Indonesia, 1-6.

Iii, B. A. B., \& Penelitian, A. J. (2013). MA Furqon. 1-18. http://etheses.uinmalang.ac.id/1749/7/09410177_Bab_3.pdf

Kompas. (2020). Rekap Kasus Corona Indonesia Selama Maret dan Prediksi di Bulan April. Kompas.Com.

Luthfi, M., Amin, I. H. Al, \& Cahyono, T. D. (2019). Analisis Pengaruh Berita Di Media Sosial Terhadap Persepsi Mahasiswa Fakultas Teknologi Industri Universitas Atma Jaya Yogyakarta. PProceeding SINTAK 2019, 1, 471-477. http://repository.radenintan.ac.id/7375/1/SKRIPSI LENGKAP HADI.pdf

Ma'ruf, M. A. (2017). Analisa Penggunaan Instagram Sebagai Media Informasi Kabupaten Nganjuk. In Equilibrahim. Universitas Islam Negeri Sunan Kalijaga Yogyakarta. 
Marini, R. (2019). Pengaruh Media Sosial Tik Tok Terhadap Prestasi Belajar Peserta didik di SMPN 1 Gunung Sugih Lab. Lampung Tengah.

Nastiti, A., Kusumah, S. W. D., Wangsaatmaja, A., Roosmini, D., Sundana, E., \& Sutadian, A. (2020). PERSEPSI RISIKO DAN BIAS KOGNITIF DALAM PENCEGAHAN PENULARAN COVID-19 DI JAWA BARAT, INDONESIA. Creative Research Journal. https://doi.org/10.34147/crj.v6i2.282

Nastiti, A., Widya, S., Kusumah, D., Wangsaatmaja, A., Roosmini, D., \& Sundana, E. (2020). Penularan Covid-19 Di Jawa Barat , Indonesia Risk Perception and Cognitive Bias in Covid-19 Prevention in West Java , Indonesia. CR Journal |, 6(2), 107-116.

Ni'matul Rohmah, N. (2020). Media Sosial Sebagai Media Alternatif Manfaat dan Pemuas Kebutuhan Informasi Masa Pandemik Global Covid 19 (Kajian Analisis Teori Uses And Gratification). Al-I'lam: Jurnal Komunikasi Dan Penyiaran Islam, 4(1), 1-16. http://journal.ummat.ac.id/index.php/jail/article/view/2957/1905

Prastiwi, D. (2020). Update Senin 28 Desember 2020: 719.219 Positif Covid-19, Sembuh 589.978, Meninggal 21.452.

Rachman, F. F., \& Pramana, S. (2020). Analisis Sentimen Pro dan Kontra Masyarakat Indonesia tentang Vaksin COVID-19 pada Media Sosial Twitter. Health Information Management Journal ISSN, 8(2), 2655-9129. https://inohim.esaunggul.ac.id/index.php/INO/article/view/223

Rohmah, N. N. (2020). Media Sosial Sebagai Media Alternatif Manfaat dan Pemuas Kebutuhan Informasi Masa Pandemik Global Covid 19 (Kajian Analisis Teori Uses And Gratification). Al-I'lam: Jurnal Komunikasi Dan Penyiaran Islam, 4(1), 1-16.

Saifuddin, M. F. (2018). E-Learning dalam Persepsi Mahasiswa. Jurnal VARIDIKA, 29(2), 102-109. https://doi.org/10.23917/varidika.v29i2.5637

Susilo, B. E., Kurniasih, A. W., Purwinarko, A., \& Fianti, F. (2018). Analisis Kompetensi Mahasiswa S1 FMIPA Melalui Pengembangan Model Evaluasi Berwawasan Konservasi Inovatif Tes Komprehensif Online. PRISMA, Prosiding Seminar Nasional Matematika, $1,49-58$.

Terbit, K. (2021). Sejarah hari ini. 1-5.

Utami, A. R. W. (n.d.). MEDIA SOSIAL MENJERAT MANUSIA DI MASA PANDEMI. 